UDC 82-1

DOI https://doi.org/10.32782/tps2663-4880/2021.15.19

\title{
COMMENTARY AND PUBLICATION DATE OF FUZULI'S PREFACES
}

\section{КОМЕНТАРІ ТА ДАТА ПУБЛІКАЦІї ПЕРЕДМОВ ФУЗУЛІ}

\author{
Pashayeva Sevinj, \\ orcid.org/0000-0002-6333-0651 \\ Chief Specialist at the Department of Scientific Publications and Forecasting \\ Institute of Literature named after Nizami Ganjavi of Azerbaijan National Academy of Sciences
}

The article refers to the work of one of the prominent figures of world literature, genius poet and thinker Mohammad Fuzuli. Known as an unparalleled master of lyrical poetry not only in Azerbaijani literature, but in the world literature, Mohammad Fuzuli has passed a rich creative path full of artistic achievements. According to Fuzuli, poetry is a divine grace that praises people. The poet sees the basis of writing beautiful poetry in science and states in the preface of his "Divan" written in the Azerbaijani language that he studied all sciences. Unique examples of the poet's poetry, which is at an inaccessible peak on the poetic horizon, have gained worldwide fame. The work of the poet, who wrote unique works in Azerbaijani, Persian and Arabic languages, has been studied by philologists for centuries. Fuzuli's inexhaustible creativity, with its richness, still opens the way to new research topics. It is known that Mohammad Fuzuli, who created beautiful examples of poetry in Azerbaijani, Persian and Arabic languages, is the author of unique "Divan" works in three languages. "Divan" is a Persian word and means a collection. It is called a collection of works of a poet in Eastern countries. This article explains the beginnings of these perfect "Divan" inherited by the poet and looks at the history of publication. "Dibache" is an Arabic word and means introduction. In classical literature, the introduction at the beginning of "Divan" and manuscripts is the name given to the preface. The preface explains the reason for writing the author's work, style, leading idea of the work, in whose name the work was written and to whom it was presented. Arabic and Persian words predominate in the prose, which is mainly in the form of prose.

Unfortunately, the manuscripts of the "Divan" written by the great poet have not reached us. However, due to the great interest and love for the poet's work, "Divan" was repeatedly copied and distributed by various secretaries. There are 247 manuscripts of "Divan" written by the poet in the Azerbaijani language in the world libraries. 43 of these manuscripts are Baku copies preserved in the fund of the Institute of Manuscripts of ANAS. "Divan" has been published in our country several times in Cyrillic and Latin script. 30 copies of the Persian "Divan", including Fuzuli's preface, are preserved. Although Fuzuli compiled "Divan" in Arabic, we know only 11 verses from this "Divan".

Key words: Mohammad Fuzuli, Divan, prefaces, explanation of the prefaces, history of publication of prefaces.

У статті йдеться про творчість одного з видатних діячів світової літератури, геніального поета і мислителя Мохаммада Фузулі. Мохаммед Фузулі, що відомий як неперевершений майстер ліричної поезії не лише в азербайджанській літературі, а й у світовій літературі, пройшов багатий творчий шлях, повний мистецьких досягнень. На думку Фузулі, поезія - це божественна благодать, яка хвалить людей. Поет бачить основу написання красивої поезії в науці і в передмові свого «Дівана», написаного азербайджанською мовою, стверджує, що він вивчав усі науки. Унікальні зразки поезії поета, яка перебуває на недоступному піку на поетичному обрії, здобули світову популярність. Творчість поета, який написав унікальні твори азербайджанською, перською та арабською мовами, вивчалася фрілологами століттями. Невичерпна творчість Фузулі своїм багатством усе ще відкриває шлях до нових дослідницьких тем. Відомо, що Мохаммад Фузулі, який створив чудові зразки поезії азербайджанською, перською та арабською мовами, $є$ автором унікальних творів «Діван» трьома мовами. «Діван» - це персидське слово і означає колекцію. Цим словом називають збірку творів поета у східних країнах. У цій статті пояснюється початок цього ідеального "Дівана», успадкованого поетом, та розглядається історія публікацій. "Dibache" - це арабське слово, що означає вступ. У класичній літературі вступ на початку «Дівана» та рукописів - це назва, яка дана передмові. У передмові пояснюється причина написання авторської роботи, стиль, провідна ідея твору, на ім'я кого написано твір і кому подаровано. У прозі переважають арабські та персидські слова, які в основному мають форму прози.

На жаль, рукописи «Дівана», написані великим поетом, до нас не дійшли. Однак через великий інтерес і любов до творчості поета «Діван» неодноразово копіювали і поширювали різні секретарі. У світових бібліотеках $є 247$ рукописів «Дівана», написаних поетом азербайджанською мовою. 43 з цих рукописів - це бакинські копії, що зберігаються у фонді Інституту рукописів НАНА. «Діван» виходив у нас кілька разів кирилицею та латиницею. Збережено 30 примірників перського «Дівана», включаючи передмову Фузулі. Хоча Фузулі склав «Діван» арабською, ми знаємо лише 11 віршів з цього «Дівана».

Ключові слова: Мохаммад Фузулі, «Діван», передмови, пояснення передмов, історія публікації передмов.

Introduction. One of the prominent figures of world literature, the great poet and thinker Muhammad Fuzuli is at an inaccessible peak on the poetic horizon. Both worldly and divine love are reflected in his unique poetry. The work of the poet, who wrote unique works in Azerbaijani, Persian and Arabic languages, had a great impact on the deve- lopment of Azerbaijani and all Eastern literature. The genius poet's work caused many imitations in the following centuries. Fuzuli's work, along with creating a completely new era in Azerbaijani literature, determined the future development of Azerbaijani poetry.

One of the most famous representatives of the divan genre in the history of Azerbaijani liter- 
ature, Mohammad Fuzuli is the author of three excellent "Divan" written in Turkish, Persian and Arabic. "Divan" is a Persian word and means a collection. It is called a collection of works of a poet in Eastern countries. In the composition of the divan there are poems, ghazals, continents, etc. The poems are expected to be sorted by genre, then these poems are arranged in alphabetical order based on the last letter of the rhyme.

Analysis of recent research and publications. The following works by various authors have been written on this subject: M. Cunbur "A Bibliographic Experiment About Fuzuli" [3], G. Aliyeva-Kangarli "Sources of Azerbaijan Fuzuli studies"[1], G. AliyevaKangarli "Language in Fuzuli poetic system" [2], "Fuzuli Mahammad Suleyman oglu. Works" [4], "Fuzuli, Fuzuli Divani" [9], A. Karahan "FUZULI (d. 963/1556): One of the Greatest Poets of Classical Turkish Literature" [10], M.F. Koprulu "Our Old Poets: Anthology of Divan Literature-Fuzuli" [11], H. Mazıoglu "Fuzuli-Hafiz. Comparison between Two Poets Muhammad" [12], Fuzuli. "Bibliography" [13], Mir Jalal "Fuzuli creativity" [14], Sh. Kuzucular "Fuzuli Turkish Divan and Selections from Poems" [15], S. Sadiqi "Majmaul-khavas" [16], Shahamettin Kuzucular "Fuzuli Arabic and Persian Divan" [17], A.N. Tarlan "Fuzuli Divani Şerhi" [18], etc.

Discussion. The works of the poet "Divan" begin with a preface. Preface is an Arabic word and means introduction. In classical literature, the introduction at the beginning of "Divan" and manuscripts is the name given to the preface. The preface explains the reason for writing the author's work, style, leading idea of the work, in whose name the work was written and to whom it was presented. Arabic and Persian words predominate in the prose, which is mainly in the form of prose.

Fuzuli's Divan, written in Azerbaijani Turkish, begins with a prosaic preface: "Həmdi-bihədd, ol mütəkəllimi-nitqafərinə ki, səfineyi-ümmid sükkanibiharibühuri-nəzmi təməvvüci-istiğraqi "vəşşüəraü yəttəbiühümül-ğavun" müstəğrəqi-girdabi-hirman etmişkən, silsileyi-istisnai - "illəl-ləzinə amənu", buraqub, şüərayi-islami səhihü salim sahili-nəcatə çəkmiş" [4, p. 26]. Fuzuli agrees with the views expressed in the Koran on poetry and poets, and expresses the need to write poetry in accordance with the principles of faith and morality.

In the "Introduction" section, Fuzuli describes the qualities of being a perfect poet, the rules of style in poetry, the relationship between science and poetry, the value of poetry, the reflection of the poet's nature in poetry, the judgments of classical poetry, the rhetorical and emotional context of poetry, the essence of poetry explains to the reader important points such as mastery.

According to Fuzuli, poetry is a divine grace that praises people. God has bestowed the gift of poetry on very few servants. The poet sees the basis of writing beautiful poetry in science and notes that he studied all the sciences by working day and night. Fuzuli explains his views on poetry in the preface of his "Divan" written in the Azerbaijani language [4, p. 29]. Fuzuli's creativity, understanding of life and the universe, and his thoughts on man are evident in his poems. According to him, the essence of poetry is love, and the basis is science.

1. There are many manuscripts of "Divan" written by Fuzuli in the Azerbaijani language in our country and abroad. However, none of these manuscripts preserved in museums around the world were written by the poet himself. As there was no printing house in Fuzuli's time, his works were copied and distributed in manuscript form. There are some differences between the manuscripts that have survived to the present day, based on some of the distortions made by the scribes during these translations. There are about 300 manuscripts of this Divan in libraries around the world. 43 of these manuscripts are Baku copies preserved in the fund of the Institute of Manuscripts of ANAS. Manuscripts in libraries around the world include:

1. Tehran Sipehsalar Madrasa Library - 307. Date: h. X (m. XVI) century. Nastaliq. Volume: 151 ver. Copied by the author in his time.

2. Istanbul University Library t.u. 5465. Date: h. 979 (m.1571/72). Nastaliq. Volume: 96 ver. Dimensions: 18 x $26 \mathrm{~cm}$.

3.LibraryofKonya MevlanaMuseum-404(special No. 2 (127). Secretary: Hussein ibn Gulshani Teacher - Kashi. Date: h. 984 (m.1576). Nastaliq. Volume: 88 ver. Size: 11.5 x $19.5 \mathrm{~cm}$.

4. Education Authority Ankara General Library 101. Date: h. 984 (m.1576). Nastaliq. Volume: 100 ver. (1b-14b from the Turkish divan). Dimensions: $14.5 \mathrm{x}$ $207 \mathrm{~cm}$. It was copied in Karbala.

5. Tbilisi Institute of Manuscripts - L 22. Secretary: Ali Valed Memed bek Shamli. Date: h. 984 (m.1577). Nastaliq. Volume: ver. 2-40. Dimensions: $13.5 \mathrm{x}$ $21.5 \mathrm{~cm}$. [9, p. 9].

Baku copies:

1. BAI. M - 236. Secretary: Mahmoud bin Davud Umunyavi. Date: h.980 (m.1572). Nastaliq. Volume: 77 ver. Size: $15 \times 27 \mathrm{~cm}$.

2. BAI. B - 2953. Secretary: Mohammad Bagir's father Mir Mohammad Garachinar. Date: h. 1011 (m.1602). Nastaliq. Volume: 122 ver. Size: $15 \times 29 \mathrm{~cm}$. 
3. BAI. M - 274 / III. Secretary: Dovletshah ibn Hussein Kalt Sarahchi. Date: h. 1053 (m.1643). Nastaliq. Volume: 68 ver. Size: $21 \times 31 \mathrm{~cm}$.

4. BAI. S. - 192. Secretary: Haji Muhammad ibn Haji Gulmammad. Date: h.1085 (m.1674). Nastaliq. Volume: 169 ver. Size: $15 \times 27 \mathrm{~cm}$. Together with "Leyli and Majnun".

5. BAI. S - 773. Date: h.1094 (m.1682). Nastaliq. Volume: ver. 1b-118a. Together with Bangu-Bada. and so on [16, p. 21].

In addition, there are 42 manuscripts of some poems and ghazals included in the Divan in world libraries, 17 of which are Baku copies.

Sadiq Bey Sadigi Afshar states in his work "Majmaul-khavas" written in 1007 (m.1598) that he read the work written by Fuzuli in his own handwriting [18]. However, the poet's manuscript is still unknown to science. Well-known scholar Y.E. Bertels, who studies Fuzuli's legacy, says: "I have reviewed the catalogs of almost all European libraries and observed the following. There are 41 manuscripts of our poet's seven works in Europe; apparently this number is large, but 13 of them are defective and only 9 are dated; as three of these manuscripts date back to the 16th century, one to the 18th century and two to the 19th century".

Bertels notes that the collection of Fuzuli, which was proved to have been written in 997 (1589-90) and kept at the St. Petersburg Institute of Oriental Studies, is the oldest and most complete Fuzuli manuscript in the world's museums. However, the prominent scholar Hamid Arasli notes and describes that the manuscript donated by the late scientist Salman Mumtaz to the Republican Manuscripts Fund of the Academy of Sciences of the Azerbaijan SSR is the oldest copy: this manuscript of 2062 consists of 65 pages; The size is $26.2 \times 15.2 \mathrm{~cm}$. There are 20 lines on each page. Written on thick, yellow paper. The line is nasty. The preface and the ghazals are separated from each other. They both start with a small, elegant pattern $[4$, p. 8$]$.

According to the dates mentioned in the divan, the end of the divan was completed on the 3rd of Muharram 977. According to another date, the Divan was copyed in 980 (1573) by Mahmud ibnDawud Ulunyavi, nicknamed Saidi. H. Arasli notes that this copy, copied after the poet's death, is the rarest copy in the world, not only because of its antiquity, but also because of its perfection and accuracy.

$\mathrm{H}$. Arasli notes that 30 of the ghazals in this edition are not in the Leningrad edition, 11 in the Istanbul edition, 5 in the Tabriz and 32 in the Tashkent edition, and states that it is based on the scientific publication because it is the most perfect copy.
The ghazals about love in "Divan" are one of the most prominent examples of lyrical poetry in Turkish literature. 295 ghazals; "Divan", which consists of tarjiband, tarkiband, mukhammas, murabbe, qita and rubai, has been repeatedly printed in stone with old letters. The first edition of the Azerbaijani "Divan" was published in Arabic in the "Bulak" printing house in Egypt. Another publication was posted online by the University of Toronto in 2007 [10, Toronto Un.: Web]. The work, first published in Tabriz with a Hijri date, has more than fifty publications in Baku, Khiva, Cairo, Istanbul and Ankara. Numerous researches have been carried out on Fuzuli "Divan", which has been repeatedly published in our new alphabet in modern times.

Fuzuli's "Divan" written in Azerbaijani is the most famous work of the poet, which shows his artistic power. This work of the poet was published by Abdulbagi Golpinarli ("Fuzuli Diwani", Istanbul 1948 and "Fuzuli Diwani", 1961), Ali Nihad Tarlan ("Fuzuli Diwani", Istanbul 1950) and Kenan Akyuz, Shedit Yuksel, Mujgan Cunbur, Ankara 1958 and Fuzuli Diwani, Ankara 1990). Ali Nihad Tarlan commented on the poet's "Divan" in the Azerbaijani language ("Commentary on Fuzuli's Divan", Ankara 1998), and Nahid Aybet researched the examples of material culture included in Fuzuli's "Divan" [12; 13; 14; 15; 16].

Fuzuli's ghazals are the pearls of his poetry, and the love legend "Leyli and Majnun" is the crown of his creativity. The theme of "Leyli and Majnun", one of the common themes of Arabic, Iranian and Turkish literature, is most effectively and sincerely expressed in Fuzuli's work.

The Institute of Oriental Studies of the Russian Academy of Sciences keeps a list of 12 manuscripts of "Leyli and Majnun". The preface of Fuzuli's "Leyli and Majnun" consists of one prose and three rubai. The prefaces written by Fuzuli to "Divan" and "Leyli and Majnun" are the best examples of poetic prefixes. The work "Leyli and Majnun" occupies an important place in Fuzuli's work, the preface of the work reflects the poet's attitude to life, man, religious and ethical views. Since the leading theme of the work is divine love, the poet expressed his thoughts on pantheistic love in poetic language. Many Soviet researchers were forced to deny or hide the glorification of Fuzuli's work in their works. But the truth is that the thoughts, progressive ideas, poetic perfection expressed in Fuzuli's poem "Leyli and Majnun" can be analyzed only by studying from the point of view of Sufism. In the first rubai at the beginning of "Leyli and Majnun", Fuzuli said that love was an important factor in the creation 
of the universe, and then began to pray to God, who has a creative nature.

Ey naş'əti-hüsni-eşqa to 'sir qulan!

Eşqifa binayi-kövni to'mir qulan!

Leyli sari-zülfini girehgir qulaü!

Macnuni-hazin boynuna zancir qulan! [6, p. 10].

In the prefaces written by Fuzuli in artistic and philosophical expressions, it is possible to analyze his worldview, view of the universe and man. Fuzuli talks about man and existence with great enthusiasm. According to him, the main essence of the poem is love. In this sense, the driving force of existence is love. Love is the most important driving force for building human relationships and sustainability.

In the preface of "Divan" written by Fuzuli in Persian, the existing thoughts of the thinker about God, the prophet and the descendants of the prophet are reflected. "May the blessings of Allah be upon the owner of the Prophethood, his great progeny and his esteemed Companions. They are the ones who carry the banner of religion and bring us the clear law of God. May God be pleased with them!"' [6, p. 13]. The love in Fuzuli's poems is more divine than human. That is, Fuzuli is in love with God. For this reason, the idea of Sufism occupies an important place in his poems.

Fuzuli stated that he used many nicknames in the preface of the Persian "Divan" and wrote beautiful poems with these nicknames, and these nicknames were quickly adopted by many poets. That's why he started writing poetry under the pseudonym "Fuzuli", which no one uses to avoid this confusion. The poet wrote about it in the preface of the Persian "Divan": "Just as when I started a poem, I liked a nickname every day, after a while I met a poet who used the same nickname, and I changed the nickname I got. Then it turned out that the friends who came before me took more nicknames than phrases. I thought that if I took a common nickname in poetry, I would be persecuted if I did not succeed, and if I succeeded, I would be persecuting my partner. In order to eliminate this similarity, I took the nickname Fuzuli and took refuge under the protection of my nickname in order to avoid my partners oppressing me and leaving me in pain" [6, p. 18].

According to Fuzili, poetry serves to reveal thoughts and feelings, to explain a person and to show some issues. The aim is to express the existence of poetry in poetic language. The poem should contain a short and meaningful word, a person expresses himself in words. On the other hand, the word is an element of creation, the word is related to the person who says it, the one who increases the value of the word increases its value. According to Fuzuli, the poet is the ruler of the land of poetry and prose. "It is known that Fuzuli created both the original WORD itself and its science and aesthetics. All the philosophical and aesthetic provisions of the poet are cited only in his works. The prefaces of the Azerbaijani and Persian "Divan", the theoretical and aesthetic ideas in the introduction of "Leyli and Majnun" are what the scientist Fuzuli said about the poet Fuzuli. Fuzuli's aesthetic views, the concept of art are based on Fuzuli's WORD art. This leads to the conclusion that Fuzuli is the founder of the world, including Azerbaijani physiology" [1, p. 17].

Fuzuli often used the verses of the Qur'an in his work. The verses of the Qur'an are a treasure and a source of inspiration for the poet. According to Fuzuli, all the features of poetry are preserved by God, and it is impossible to write a perfect poem without his help. These ideas are reflected in the preface of the Azerbaijani "Divan" in the following form: "Və dürudi-namə' dud ol müxatəbi-kəlami-möciznizamə ki, fünuni-şe'ri məzmuni - "və ma əlləmnahuş-şe'rə" mərdudi-təbaye q1lmış ikən lisani-hikmətbəyani "innə minəş-şe'ri ləhikmətün"1 təqriri-dilpəzirilə məqbuliqülubiəhli-hal etmiş. Və sənayi-biriya ol qafiyeyi-nəzmi-ənbiyayə $\mathrm{ki}$, ədəmi-iltifatlərilə rütbeyi-şe'r payeyi-ihanətdə qalmışkən, silsileyi-səadətintisabi-şəriflərilə filcümlə dərəceyi-e'tibarə yetmiş.

Ol düri-dürci-"əna afsah" ki, hikmat dayasi,

Şe'r şahdila labi-canparvarin tar qulmamış.

Şe'r bir zirvadir, amma biz kimi naqislara,

Ol ki, kamildir, onu möhtaci-zivar qulmamış"

[4, p. 26-27].

According to Fuzuli, God attached importance to the perfect word and created man in a nature that enjoys the beautiful word. Fuzuli characterizes this grace given to man by God as the most sublime and inaccessible creator. According to the poet, the greatest artist is God, and the heavens and the earth are small signs of God's infinite mastery. God, who created human beings as living beings, endowed them with some of its attributes, that is, hearing, seeing, power, speech, science, invention, mercy, love, anger, grace, generosity, and so on.

Fuzuli's Persian "Divan" is larger than the Azerbaijani "Divan". The Persian Divan contains 49 verses, 410 ghazals, 3 musammats (1 tarjiband, 1 murabbe, 1 musaddas), 46 qita and 105 rubai. The translation of the work into Turkish was published in 1950 by Ali Nihad Tarlan, and the scientific critical edition was published in 1962 by Hasiba Mazioglu. A 134-verse Persian poem entitled "Anisul-Qalb" ("Friend of the Heart"), which is also considered a separate work in some sources, is included 
in the verse section of Fuzili's Persian "Divan". A copy of Fuzuli's Persian Divan was found in the Muradiya Library in Manisa, Turkey (registered under number 2668), in the Carullah Efendi section of the Fatih National Library (registered under 1670), and in the Persian Manuscripts section of the Istanbul University Library (registered under 883). In addition, another copy of the Persian "Divan" was found among the books of Ismail Saip Sanjar. It should be noted that Ismail Saip Sanjar has been the librarian and director of the "General Ottoman Library" for 43 years, which today operates as the Bayazid State Library. The famous Turkish historian, literary scholar Ali Nihat Tarlan completed the translation of the Persian "Divan" into Turkish in 1950. Ali Nihat played an important role in the publication of a number of works by Tarlan Fuzuli. Ali Nihat Tarlan's work "Commentary on the Fizuli Divan" has been published 11 times, the last study was published in 2017 [13].

Volume III of the five-volume "Works of Fuzuli" compiled by academician H. Arasli in 1958 contains the poet's "Divan" in Persian. The book contains the preface of "Divan", 375 ghazals, 94 rubai, 44 continents and 1 hatima. However, the number of these ghazals in the reprints of the poet's works published in 1996 and 2005 is 386 [6].

In modern times, Fuzuli's manuscripts are preserved in many famous libraries around the world. For example, some of the poems contained in the poet's "Divan" in Azerbaijan are registered in the Bermen State Library. No. 41, p. 80; No. 29, p. 59; No. 327 , p. 329 ; No. 325 , p. 328 ; No. 340 , p. 343 ; No. 349, p. 346; No. 350 , p. 347.

In modern times, the poet's works, along with the Azerbaijani language, Turkish, Uzbek, Turkmen, Russian, Ukrainian, German, English, French, Italian, Polish, Czech, Romanian, Hungarian, Latvian, Lithuanian, Arabic, Persian, Afghan, Urdu, Turkmen, Georgian published in many languages. From this point of view, the poet's works have been published in more than twenty languages. The first publication of Fuzuli's works in our native language took place in Tabriz in 1851, in this edition the works "Kulliyyati-divani-Fuzuli", "Bangu bade", "Haft cam" were published.

The bibliography of Mohammad Fuzuli, published in 2011, contains 4864 works. It contains manuscripts of the poet preserved in various libraries around the world, as well as a collection of published works of the poet in different languages, research works on the poet's work. This extensive list also includes Baku copies of the poet's works. Fuzuli has 17 copies of the Azerbaijani "Divan" in Baku, all 17 of which are preserved at the Institute of Manuscripts. For example:

1. Institute of Manuscripts. fond. 24, s-v.146. Secretary: Salman Mumtaz. History: Early twentieth century. Nastaliq. Volume: $30 \mathrm{~s}$. Dimensions: $26.5 \mathrm{x}$ $35.5 \mathrm{~cm}$. In Azerbaijani and Persian languages.

2. Institute of Manuscripts. B - 2636. Secretary: Abbas ibn Ali Muhammad. Volume: ver. 39a-41a.

3. Institute of Manuscripts. S - 1091. Compiled by: Huseyn efendi Gaibov. Volume: ver. 259a-259b, 268-269b.

30 copies of the Persian "Divan", including Fuzuli's preface, are preserved, for example, we can mention the following:

1. Manisa Muradiye Library - 2668. Secretary: Habibullah Isfahani. Date: h. 959 (m.1552). Copied in Baghdad.

2. Education Authority Ankara General Library 101. Date: 984 (m.1576). It was copied in Karbala. It is also given in the Turkish divan in $1 \mathrm{~b}-14 \mathrm{~b}$.

3. Istanbul Suleymaniye Library (Lalali part) 1912. Date: h. 999 (m.1590 / 91). Nastaliq. Volume: ver. $18 \mathrm{a}-80 \mathrm{~b}$.

4. Tehran University Library - 4577. History: h.x (m.XVI) century, Nastaliq. Volume: 176 ver. Dimensions: 12 × $20 \mathrm{~cm}$.

5. Tehran University Library - 5092. Date: h. X-XI (m. XVI-XVII) centuries. Nastaliq. Volume: 105 ver. Dimensions: 15 x $24 \mathrm{~cm}$.

Baku copy:

1. BAI, B - 1394 / IX. Date: h. 1273 (m. 1855). Nastaliq. Volume: ver. 189b-199a. Size: 18 x 29 [15, p. 28-29].

Although Fuzuli compiled the Divan in Arabic, we have received only eleven verses from this Divan. The first person to study Fuzuli's "Divan" in Arabic was the famous orientalist, corresponding member of the USSR Academy of Sciences Yevgeny Eduardovich Bertels. Bertels not only studied Fuzuli's Divan in Arabic, but also translated two poems from Divan into Russian. Academician Hamid Arasli studied these manuscripts and published them in 1958 under the title "Matla ul-Itiqad and Arabic Poems". The treatise "Matla ul-Itiqad", which reflected Fuzuli's philosophical views, was also in Arabic. Fuzuli's Arabic "Divan" was translated into Turkish by Esat Coshan and Kemal Isik and published in 1962 by the Turkish Historical Society. Unfortunately, Arabic poems are not included in this translation. There are different opinions about the size of the Divan in Arabic. Citing Bertels, Fuad Köprülü says that the 465 -verse divan consists of 11 verses and one ending. The longest of these poems is 63 verses and the shortest is 21 verses. Abdulgadir 
Garakhan notes that the number of verses in "Divan" is 470, Hamid Arasli - 516. The poet's "Divan" in Arabic is less published than "Divan" in Azerbaijani and Persian languages:

1. Institute of Oriental Studies of the Russian Academy of Sciences. SPb. S - 1924. Date: h. 997 (m. 1588/89). Nastaliq. Volume: ver. 189b-199a. Dimensions: 18 x 29 .

2. Matlaul-etiqad and Arabic poems / Compiled by: H. Arasli. Baku: Azerbaijan. SSR EA Publishing House, 1958, $204+7$ p. In the Arabic alphabet.

3. Matlaul-itikad, fi marifetil mebde vel-mead/ Preparedby the publisherwith theaddition offorewords and notes: Muhammad Tavit et-Tanji; Translators: M. Esad Joşan and Kemal İsık. Ankara, 1962.

Hamid Arasli is one of the leading scholars studying classical Azerbaijani literature by modern methods, with the intensity and breadth of his work. During the Soviet era, the famous literary scholar, academician Hamid Arasli did serious work in the field of researching the legacy of Fizuli and publishing his works. In 1940, Fuzuli's "Selected Works" ("Leyli and Majnun"), designed by Hamid Arasli, was published by Azerneshr Publishing House. As a result of Hamid Arasli's activity, the works of the great poet were published in two volumes in the 1940s, the compiler and editor of both volumes is Hamid Arasli. The first volume of the poet's lyrics, the beginning of his divan, ghazals, continents, rubais was published in 1944, "Leyli and Majnun", "Bangi bade", "Sohbatul asmar", poems, mysteries; The second volume, consisting of a translation of "Hadisi Arbain", "Complaint" and "Letter to Gazi Alaiddin", was published in 1949 by the publishing house of the Academy of Sciences of Azerbaijan.

Academician Hamid Arasli continued his research in the following years and managed to publish Fuzuli's works in five volumes. The first volume, published in 1958, contains the preface of Fuzuli's divan in the Azerbaijani language, ghazals, taribands, compositions, mukhammas and jams, continents, rubais. The second volume of the collection includes the poet's translations of "Leyli and Majnun", "Bangu Bade", "Sohbatul Asmar", "Mysteries", "Hadith-Arbain", "Complaint" and "Letters". In the third volume, published in the same year, the poet's Persian "Divan" preface, ghazals, continents, rubais were published.
The fourth volume of Fuzuli's poems, the preface of Fuzuli's poems, Azerbaijani poems, Persian poems, Arabic poems, "Anisul-Qalb" and "Admonition to Fazli" was published in 1961 [7]. In 1985, the fifth volume of the collection was published. In this volume, the poet's works "Rindu Zahid", "Health and Disease", "Matlaul-etiqad", "Gitalar", "Yeddi Jam", composition, Persian poems, ghazals, mulammas, mustazad, dubeyti and muhammas [7] were collected.

In 1995, Fuzuli's works were published in two volumes by the Azerbaijan Encyclopedia NPB, and in 1996, all known works of the poet were published in six volumes by the Azerbaijan Publishing House. The six-volume works of the poet were republished in 2005 by the East-West Publishing House in Latin script. The compiler of volumes $\mathrm{I}-\mathrm{V}$ of his works is Hamid Arasli, and the compiler of the VI volume is professor, corresponding member of ANAS Aliyar Safarli [15]. Aliyar Safarli was closely involved in the compilation and publication of the poet's work "Hadikatus-Suada" ("Garden of Happiness"). The editor of all volumes is a well-known literary critic, full member of ANAS Teymur Karimli.

Fuzuli's work, which has been studied by philologists for centuries and is inexhaustible, with its richness still paves the way for new research topics. The opinion of the prominent literary scholar Mir Jalal Pashayev about Fuzuli's work is still confirmed today: "It is not the work of one person, one scientific school, or even one scientific generation to analyze and determine the power, scale and merits of Fuzuli art" [16, p. 4].

In modern times, serious work is being done to study Fuzuli's legacy, interpret his works, study his manuscripts and publish the poet's works in different languages. It should be noted that "Fuzuli wrote in three major languages of the East - Turkish, Arabic and Persian, created "Divan" in three languages, created philosophical treatises with masterpieces, poems and prose such as "Leyli and Majnun" in his native language" [2].

Conclusions. Mohammad Fuzuli, who is said to be from the famous Bayat tribe of Azerbaijan, is known as one of the greatest representatives of the divan genre. We believe that in the future, the rich creativity of Fuzuli, which is an integral part of our spiritual heritage, will be introduced to the world, and his works will be published in different countries.

\section{REFERENCES:}

1. Aliyeva-Kangarli G. Sources of Azerbaijan Physiology. In 3 volumes. I volume. Baku : Education, 2011

2. Aliyeva-Kangarli G. Language in the poetic system of Fuzuli. 525th newspaper. Baku, 2012.

3. Cunbur M. A Bibliographic Experiment About Fuzuli, Istanbul 1956. Fuzuli Muhammad Suleyman oglu. Works: in 6 volumes. Volume I / Compiled by: H. Arasli; Ed.: T. Kerimli. Baku : "East-West", 2005. 400 p.

4. Fuzuli Muhammad Suleyman oglu. Works: in 6 volumes. Volume II / Compiled by: H. Arasli; Ed.: T. Kerimli. Baku : East-West, 2005. 336 p. 
5. Fuzuli Muhammad Suleyman oglu. Works: in 6 volumes. Volume III / Compiled by: H. Arasli; Ed.: T. Kerimli. Baku : East-West, 2005. 472 p.

6. Fuzuli Muhammad. Works: in 5 volumes. Volume IV / Compiled by: H. Arasli; Ed.: H. Arasli, H. Mammadzade.

Baku : Publishing House of the Academy of Sciences of the USSR, 1961. $393 \mathrm{p}$.

7. Fuzuli Muhammad Suleyman oglu. Works: in 5 volumes. Volume V / Compiled by: H. Arasli; Ed.: H. Mammadzade, A. Ahmadov. Baku : Elm, 1985. 216 p.

8. Fuzuli Muhammad Suleyman oglu. Works: in 6 volumes. Volume VI / Compiled by: A. Traveling; Ed.: T. Kerimli. Baku : East-West, 2005. 384 p.

9. Fuzuli, Fuzuli Divani / published by Kenan Akyuz et al., Ankara. 1990.

10. Karahan A. FUZÛLî (d. 963/1556): One of the greatest poets of classical Turkish literature. URL: https://islamansiklopedisi.org.tr/fuzuli.

11.Köprülü M.F. Our Old Poets: Anthology of Divan Literature-Fuzuli, Istanbul 1934, p. 193-256.

12. Kuzucular Ş. Fuzuli Arabic and Persian Divans, 2014. URL: https://edebiyatvesanatakademisi.com/ divan-siiri-ve-sairler/fuzuli-arapca-ve-farsca-divanlari/1187.

13. Kuzucular Ş. Selections from Fuzuli Turkish Divan and Poems, 2015. URL: https://edebiyatvesanatakademisi. com/divan-siiri-ve-sairler/fuzuli-turkce-divani-ve-siirlerinden-secmeler/1285.

14. Mazıoğlu H. Fuzûlî-Hâfız: A Comparison Between Two Poets, Ankara 1956.

15. Mohammad Fuzuli. Bibliography. Baku : Nurlan, 2011.

16. Mir Jalal. Fuzuli craftsmanship. Baku : Maarif, 1994.

17. Sadiqi S. Majma'ul-khawas. Baku. 2008.

18. Tarlan A.N. Fuzuli Divani Şerhi, Akçağ Yayınları, Ankara, 1998.

УДК 81'42: 811.111

DOI https://doi.org/10.32782/tps2663-4880/2021.15.20

\title{
ЮРИДИЧНИЙ АНГЛОМОВНИЙ ДИСКУРС: ОСОБЛИВОСТІ ТА ЗАСОБИ РЕАЛІЗАЦІЇ ІНТЕРТЕКСТУАЛЬНОСТІ
}

\author{
LEGAL ENGLISH DISCOURSE: \\ FEATURES AND MEANS OF INTERTEXTUALITY IMPLEMENTATION
}

\author{
Ходаковська О.О., \\ orcid.org/0000-0002-2168-4558 \\ кандидат філологічних наук, \\ дочент кафедри іноземних мов № 1 \\ Національного юридичного університету імені Ярослава Мудрого
}

\begin{abstract}
У статті розглянуто й визначено особливості реалізації категорії інтертекстуальності як засобу вираження цілісності англомовного юридичного дискурсу. Дослідження структурно-композиційних особливостей правничих текстів, незважаючи на їхню безсумнівну цінність та значущість, не пропонують системного уявлення про мову права. Необхідно розглядати процеси в більш широкому соціальному контексті функціонування мови, а саме з точки зору дискурсу. Англомовний юридичний дискурс створюється в правничому змістовному полі та покликаний передавати певний зміст, є націленим на комунікативну дію з власною прагматикою. Англомовний юридичний дискурс $є$ сукупністю різних типів правничих дискурсів та характеризується жорсткими обмеженнями на всіх рівнях макроструктури тексту, абзаців, речень та зворотів, йому властива відповідність стандартизованим фрормам, кліше та сталим зворотам, які не $є$ загальновживаними. Запропоновано огляд історії вивчення юридичного дискурсу в мовознавстві та представлено проблематику досліджуваної сфери. Сформульовано актуальні аспекти експлікації англомовного правового дискурсу через фігури інтертексту. Інтертекстуальні зв'язки, які перетворюють дискурс на єдиний елемент, поєднують елементи дискурсу. Визначено, що англомовному правничому дискурсу властива репрезентація інтертекстуальності на змістовному й формальному рівнях. Дослідження показало, що засобами реалізації категорії інтертекстуальності в дослідженому нами матеріалі $є$ цитати, непряма мова, алюзія. В англомовному правничому дискурсі використовуються розгорнуті та нерозгорнуті цитати. Нерозгорнуті цитати мають тенденцію до максимально можливого скорочення та позначають посилання на текст закону, місце, розділ і дату ухвалення положення чи закону. Відповідно до класифікації кодів Р. Барта в англомовному правничому дискурсі репрезентовані символічний, герменевтичний, семантичний, культурний та комунікативний коди. Встановлено функції маркерів інтертексту в англомовному правничому дискурсі. До них віднесено аргументативну, інформативну та роз'яснювальну функції.

Ключові слова: англомовний правничий дискурс, інтертекстуальність, текст, фігури інтертексту, елементи дискурсу, маркери інтертексту.
\end{abstract}

